\title{
Kinetic Spectrophotometric Determination of Drugs Based On Oxidation by Alkaline $\mathrm{Kmno}_{4}$
}

\author{
K.Damodar Reddy, K.Sayanna \& G. Venkateshwarlu* \\ Department of Chemistry, Nizam College/ Osmania University, Hyderabad-500001,A.P., India
}

\begin{abstract}
Simple, accurate and precise spectrophotometic methods for quantitative determination of four drugs viz., Levofloxacin (LEV), Moxifloxacin (MOX), Pseudo Ephidrine (PSE), Torsemide (TOR) have been developed based on oxidation of the drugs by alk.KMnO${ }_{4}$. Kinetics of the oxidation reaction is followed spectrophotometrically, as one of the reaction product, $M n(V I)$, absorbed at $610 \mathrm{~nm}$. Initial rate and fixed time method are used for the construction of calibration curves Beer's law is obeyed in the range 6.25-37.5 $\mu \mathrm{g} \mathrm{ml^{-1 }}$

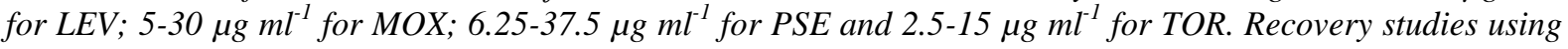
pure samples and pharmulations in the Beer's Law limits have been carried out. Excellent recoveries indicate the methods are accurate and precise. The methods have been validated in terms of ICH guidelines. Statistical analysis in terms of student's t- test and variance F- tests demonstrate high accuracy and precision and suggest the methods can be applied in bulk drug and pharmaceutical industries.
\end{abstract}

Keywords: Spectrophotometry, Determination, Drugs, $\mathrm{KMnO}_{4}$.

\subsection{Levofloxacin:}

\section{Introduction}

Levofloxacin [Fig. 1 a], (S)-(-)-9-fluro-2,3,-dihydro-3-methyl-10-(4-methyl-1-piperazinyl)-7-oxo-7Hpyrido[1,2,3-de][1,4]benzoxazine-6-carboxylic acid, a third-generation fluoroquinolone, is the active levoisomer of ofloxacin and is twice as active as the parent drug. It is active against both Gram-positive and Gramnegative bacteria. Levofloxacin is administrated to patients with urinary, respiratory or cutaneous infections, in $500 \mathrm{mg} /$ day doses. Levofloxacin is mainly excreted in urine (>85\%), in unaltered form [1].

Some analytical methods HPLC [2,3], spectrophotometry [4,5] and Spectrofluorimetry [6] have been described for determination of LEV.

\subsection{Moxifloxacin :}

Moxifloxacin (MOX) [Fig.1 b] chemically known as 1-cyclopropyl-6-fluoro-1, 4-dihydro-8-methoxy7-[(4aS, 7aS)-octahydro-6H-pyrrolo-[3, 4-b] pyridin-6-yl]-4-oxo- 3-quinolinecarboxylic acid is a fourth generation fluoroquinolone broad spectrum antibiotic agent used in Conjunctivitis [7,8].

Some methods such as HPLC [9,10], Fluorimetry [11,12], spectrophotometry [13,14] and Voltammetry [15] are used for the determination of MOX.

\subsection{Pseudo ephidrine :}

Pseudo Ephidrine (PSE) [Fig.1 c], chemically known as (S,S)-2-methylamino-1-phenylpropan-1-ol is asympathomimetic drug that has been for the relief of nasaldecongestion [16].

Literature survey reveals that there are HPLC [17,18], Capillary Electrophoresis [19],spectrophotometry [20,21] and LC-MS $[22,23]$ methods reported for the determination of PSE.

\subsection{Torsemide :}

Torsemide chemically 3-[4-[(3-methylphenyl) amino] pyridin-3-yl]sulfonyl-1-propan-2-ylurea [Fig.1 d], is a loop diuretic mainly used in the management of edema associated withcongestive heart failure. It is also used at low doses for the management of hypertension [24,25].Hydrotropy phenomenon is considered as a unique technique by which solubility for sparinglysoluble solute under normal conditions increase in the several folds[26].

Colorimetry [27], UV- Spectrophotometry [28] methods have been reported for the determination of Torsemide. 


\subsection{Instrumentation :}

\section{Expermental}

The UV-VIS spectra of the study have been recorded on SHIMADZU 140 double beam Spectrphotometer,Thermo Nicolet 1000 and also on ELICO 159 UV-VIS single beam spectrophotometers using quartz cells of $10 \mathrm{~mm}$ path length.

A Dhona 200 single pan electrical balance is used for weighing the samples.

\subsection{Materials :}

Analytical grade $\mathrm{KMnO}_{4}, \mathrm{NaOH}$ and triple distilled water was used for preparing solutions for the study.

\subsubsection{Preparation of Drug Solution:}

A stock solution of each drug containing $1000 \mu \mathrm{g} \mathrm{ml}^{-1}$ was initially prepared and further diluted to get working concentrations.

\subsection{2. $\mathrm{KMnO}_{4}$ Solution:}

A stock solution of $\mathrm{KMnO}_{4}$ is prepared by dissolving $0.158 \mathrm{gm}$ of pure sample of $\mathrm{KMnO}_{4}$ in $100 \mathrm{ml}$ triple distilled water. The permanganate solution was standardized against oxalic acid by standard procedure.

\subsubsection{Standardization of $\mathrm{KMnO}_{4}$ :}

The standardization of $\mathrm{KMnO}_{4}$ solution is carried out by titration against a standard solution of oxalic acid. Oxalic acid is a good primary standard because the compound is available in solid form, as $\mathrm{H}_{2} \mathrm{C}_{2} \mathrm{O}_{4} \cdot \mathrm{H}_{2} \mathrm{O}$, which can be prepared to a very high degree of purity and is neither hygroscopic nor efflorescent. The reaction is

$$
2 \mathrm{MnO}^{4-}(a q)+6 \mathrm{H}^{+}(a q)+5 \mathrm{H}_{2} \mathrm{C}_{2} \mathrm{O}_{4}(a q) \rightarrow 2 \mathrm{Mn}^{2+}+8 \mathrm{H}_{2} \mathrm{O}(l)+10 \mathrm{CO}_{2}(g)
$$

\subsection{3. $\mathrm{NaOH}$ Solution:}

$0.5 \mathrm{M} \mathrm{NaOH}$ solution is prepared by dissolving $20 \mathrm{gm}$ of $\mathrm{NaOH}$ in $1000 \mathrm{ml}$ triple distilled water. The same is standardized by titrating against standardized $\mathrm{HCl}$ solution.

\section{Method Development}

The method depends on the oxidation of the drug with alkaline potassium permanganate $\left(1 \times 10^{-2} M\right)$ to produce Manganate ion which absorbs at $610 \mathrm{~nm}$ and formed a basis for quantification of drug. A solution of $0.45-0.5 \mathrm{M} \mathrm{NaOH}$ is used to produce required alkalinity to the solution. Linearity and calibration curves are determined from initial rate and fixed time methods.

\section{Procedure For Kinetic Study}

A stock solution of each drug containing $1000 \mu \mathrm{g} \mathrm{ml}^{-1}$ was prepared as mentioned earlier. The drug solutions were further diluted to get required concentrations for the kinetic study.

$8 \mathrm{ml}$ of this drug solution was transferred in to $10 \mathrm{ml}$ calibrated flask, $1 \mathrm{ml}$ of $\mathrm{KMnO}_{4}\left(1 \times 10^{-2} M\right)$ and $1 \mathrm{ml}$ of $\mathrm{NaOH}$ were added. After shaking for $10 \mathrm{sec}$ the solution was transferred to a cuvette and was placed in sample compartment. Similarly prepared blank solution was placed in the reference compartment. The absorbance of this sample was measured at 2, 5, 10,15, 20, 25 and $30 \mathrm{~min}$. The procedure is repeated with $7 \mathrm{ml}$, $6 \mathrm{ml}, 5 \mathrm{ml}, 4 \mathrm{ml}, 3 \mathrm{ml}, 2 \mathrm{ml}, 1 \mathrm{ml}$ and $0.5 \mathrm{ml}$ of drug solutions by making up remaining volume with distilled water. Absorbance-time curves [Fig. 2] were constructed.

\subsection{Initial rate method:}

\section{Procedure For Calibration}

The initial rates of the reaction were determined from absorbance-time curves by measuring the slopes of the initial tangent to the absorbance time curves. Aliquots of $6.25-37.5 \mu \mathrm{g} \mathrm{ml}^{-1}$ of LEV, 5-30 $\mu \mathrm{g} \mathrm{ml}^{-1}$ of MOX, 6.25-37.5 $\mu \mathrm{g} \mathrm{ml}^{-1}$ of PSE, 2.5-15 $\mu \mathrm{g} \mathrm{ml}^{-1}$ of TOR test solutions were pipetted into a series of $10 \mathrm{ml}$ standard flasks. $1 \mathrm{ml}$ of $0.5 \mathrm{M} \mathrm{NaOH}$ followed by $1.0 \mathrm{ml}$ of $0.01 \mathrm{M}$ potassium permanganate were added to each flask and then diluted with distilled water at room temperature. The contents of the mixture of each flask were mixed well and the increase in absorbance at $610 \mathrm{~nm}$ was recorded as a function of time. The initial rate of the reaction (n) at different concentrations was obtained from the slope of the tangent to the absorbance time curve.

\subsection{Fixed time method:}

In this method, the absorbance of a green colored solution containing varying amounts of drugs as mentioned above for initial rate method were measured at a preselected fixed time, $15 \mathrm{~min}$. 


\section{Procedure For Assay Of Pure Drug}

To test the accuracy and precision of the methods developed, pure sample solutions containing drug in the Beer's Law limit were chosen and kinetics of the reaction were studied. For this study 8, 15, 22 and $29 \mu \mathrm{g}$ $\mathrm{ml}^{-1}$ of Lev; 5,10,15 and $20 \mu \mathrm{g} \mathrm{ml}^{-1}$ of Mox; 7. 14, 21 and $28 \mu \mathrm{g} \mathrm{ml}^{-1}$ of Pse; 3, 6, 9 and $12 \mu \mathrm{g} \mathrm{ml}^{-1}$ of Tor were chosen for kinetic study other experimental details being common. Initial rate and fixed time of 15 min were chosen to estimate the amount found.

\subsection{Levofloxacin :}

\section{Procedure For Analysis Of Pharmaceuticals}

Each tablet of Levofloxacin contains $500 \mathrm{mg}$ Levofloxacin as active substance. The total content of ten tablets was weighed and grounded to a fine powder using a pestle and a mortar. Powder was dissolved in $\mathrm{NaOH}$ -water filtered through a filter paper and diluted to the mark in a $100 \mathrm{ml}$ calibrated flask. Convenient aliquots from this solution were taken for the determination of Levofloxacin $\left(6.25-37.5 \mu \mathrm{g} \mathrm{m}^{-1}\right)$. Kinetics runs were performed using 9, 16, 23 and $30 \mu \mathrm{g} \mathrm{ml}^{-1}$ of Levofloxacin other experimental details being common. Initial rate and fixed time of 15 min were chosen to estimate the amount found.

\subsection{Moxifloxacin :}

For analysis of commercial formulations, twenty tablets were taken and powdered. Tablet powder equivalent to $400 \mathrm{mg}$ of Formulation were transferred into $100 \mathrm{ml}$ volumetric flask and dissolved in 0.5 $M \mathrm{NaOH}$. Then the solution was sonicated for 30 minutes and filtered. $1.25 \mathrm{ml}$ from the filtrate were taken and further diluted with $0.5 \mathrm{MNaOH}$ to form $5 \mu \mathrm{gmL}^{-1}$. Kinetics runs were performed using $6,11,16$ and $21 \mu \mathrm{gmL}^{-1}$ of Moxifloxacin other experimental details being common. Initial rate and fixed time of 15 min were chosen to estimate the amount found.

\subsection{Pseudoephedrine :}

An accurately weighed ten tablets were finely powdered, weighed, a portion equivalent to $120 \mathrm{mg}$ was transferred quantitatively into $50 \mathrm{ml}$ volumetric flask, sonicated for $15 \mathrm{~min}$, completed to volume with distilled water. A stock solution containing $2.4 \mathrm{mg} \mathrm{ml}^{-1}$ was further diluted to get required concentration for pharmaceutical analysis. Kinetics runs were performed using 6,13,20 and $27 \mu \mathrm{g} \mathrm{ml}^{-1}$ of pseudoephedrine other experimental details being common. Initial rate and fixed time of $15 \mathrm{~min}$ were chosen to estimate the amount found.

\subsection{Torsemide :}

In order to see the feasibility of proposed method for estimation of Torsemide in marketed pharmaceutical formulations, twenty tablets were weighed, average weight determined and crushed into fine powder. A quantity of tablet powder equivalent to $10 \mathrm{mg}$ of Torsemide was transferred into $100 \mathrm{ml}$ volumetric flask containing $50 \mathrm{ml}$ water, shaken manually for $10 \mathrm{~min}$, volume was adjusted to mark with same solvent and filtered through Whatmann filter paper No.1. The appropriate aliquots were transferred to $10 \mathrm{ml}$ volumetric flask, volume was adjusted to the mark with same solvent to obtain concentration of $2.5 \mu \mathrm{g} \mathrm{ml}^{-1}$. Kinetics runs were performed using $4,7,10$ and $13 \mu \mathrm{g} \mathrm{mL}^{-1}$ of Torsemide other experimental details being common. Initial rate and fixed time of $15 \mathrm{~min}$ were chosen to estimate the amount found.

\subsection{Construction of calibration :}

\section{Result And Discussion}

The absorbance data of kinetic runs at $2 \mathrm{~min}$ and $15 \mathrm{~min}$ are used to construct calibration. The average relative responses of 5 replicates were evaluated. The absorbance falling within $95 \%$ to $105 \%$ of average relative response only are considered in construction of the calibration curve [Fig.3].

The limits of Beer's law, slope, intercept, correlation coefficient, sandell's sensitivity and regression equation for each drug are tabulated in [Table 1].

\subsection{Method validation :}

Each method developed for quantification of drugs has been validated in terms of precision, accuracy, limit of detection. limit of quantification, linearity, selectivity and ruggedness. Absorbance-time curves were drawn, initial rate and fixed time methods were used to assess the recovery of the drug. To assess the precision, each experiment was repeated at least 5 times and accuracy is estimated in terms of percent recovery and percent RSD. Excellent percent recovery and RSD being less than 2 for each drug demonstrates accuracy and precision of the methods. Further t-test and F-test values have also been calculated using a standard reference method. The t-test and F-test values are less than that their permissible range indicating high accuracy and 
precision of the methods [Table 2]. As mentioned earlier, limit of detection is the minimum limit that can be detected but not necessarily quantified, is determined for each drug.

LOD is determined from the standard deviation of $y$-intercepts of regression lines of replicate determinations.

$\mathrm{LOD}=3.3 \mathrm{~s} / \mathrm{S}$

$$
\begin{aligned}
\text { Where } \mathrm{s}= & \text { standard deviation of intercept }(\mathrm{n}=5) \\
& \mathrm{S}=\text { slope of linearity plot }
\end{aligned}
$$

LOQ the minimum concentration of analyte using calibration curve is also determined.

$$
\mathrm{LOQ}=10 \mathrm{~s} / \mathrm{S}
$$

Limits of Linearity of calibration curves are mentioned in the Table 1 under the title Beer's law limit. To test the selectivity, known excipients of each drug are added to the pure drug sample and recovery experiments were performed. Ruggedness is resistance of method for a small change in variables like instrument and analyst or both. To test the ruggedness of the method absorbance data was collected using 3 different instruments and 2 analysts. No significant changes were observed either by change of instrument or analyst, hence the method may be treated as rugged.

\subsection{Effect of concentration of $\mathrm{KMnO}_{4}$ :}

\section{Factors Effecting Absorbance}

The effect of concentration of $\mathrm{KMnO}_{4}$ on the absorbance at preselected time, 15 min was studied in the range $0.2 \times 10^{-2} M$ to $1.2 \times 10^{-2} M$ by keeping the concentration of drug constant. The absorbance [Fig. 5] increased with increasing the concentration of $\mathrm{KMnO}_{4}$ and became constant at $0.7 \times 10^{-2} M$ to $0.8 \times 10^{-2} M$. Thus, the adoption of $1 \times 10^{-2} M \mathrm{KMnO}_{4}$ in the final solution proved to be adequate for the maximum concentration of drugs used in the determination process.

\subsection{Effect of $\mathrm{NaOH}$ :}

The influence of the $\mathrm{NaOH}$ concentration examined by taking fixed concentration of drug, $1.0 \mathrm{ml}$ of $0.01 M \mathrm{KMnO}_{4}$ solution and varying volumes $(0.2-1.2 \mathrm{ml})$ of $0.5 \mathrm{M} \mathrm{NaOH}$. The maximum absorbance was obtained with $0.8 \mathrm{ml}$ of $0.5 \mathrm{MNaOH}$, after which further increase in volume of $\mathrm{NaOH}$ caused no change in absorbance. Hence, 0.8 to $1.0 \mathrm{ml}$ of $0.5 \mathrm{M} \mathrm{NaOH}$ was used as antimum value [Fig. 6]

\subsection{Effect of prolonged time:}

The effect of time on the reaction between $\mathrm{KMnO}_{4}$ and the drugs was studied. The absorbance of the reaction mixture was increased with time. The solutions turned turbid after 30-35 min.

\subsection{Effect of temperature:}

At room temperature the reaction rate of four drugs increased substantially as the color development increased. Higher temperature causes precipitation of $\mathrm{MnO}_{2}$, therefore, room temperature was selected as the optimum.

\section{Analysis Of Pharmaceuticals}

To test the applicability of the method developed, solution of pharmaceutical tablets containing drug in the Beer's Law limit were chosen and kinetics of the reaction were studied. For this study 9, 16, 23 and $30 \mu \mathrm{g}$ $\mathrm{ml}^{-1}$ of Lev; 6. 11, 16 and $21 \mu \mathrm{g} \mathrm{ml}{ }^{-1}$ of Mox; 6,13, 20 and $27 \mu \mathrm{g} \mathrm{ml}^{-1}$ of Pse; 4, 7, 10 and $13 \mu \mathrm{g} \mathrm{ml} \mathrm{m}^{-1}$ of Tor were chosen for kinetic study other experimental details being common. Initial rate and fixed time of $15 \mathrm{~min}$ were chosen to estimate the amount found. Absorbance-time curves were drawn, initial rate and fixed time methods were used to assess the recovery of the drug in pharmaceuticals. To assess the precision each tablet analysis was repeated at least 5 times and accuracy is estimated in terms of percent recovery and percent RSD. Excellent percent recovery and RSD being less than 2 for each drug demonstrates applicability of the methods for pharmaceutical analysis. Further t-test and F-test values have also been calculated using a standard reference method. The closeness of t-test and F-test values are less than that they permissible range indicating excellent applicability of the methods for pharmaceutical analysis[Table 3].The excellent recovery studies indicate that methods developed can be applied to pharmaceutical analysis without hesitation.

As defined eralier Sandell's sensitivity of the analyte capable of producing a change 0.001 absorbance units is a measure of sensitivity of the method. Lower the Sandell's sensitivity higher is the sensitivity of the method developed. The Sandell's sensitivity values of drugs presented in [Table 1] indicate that Ind has lowset Sandell's snstivity and hence is highest sensitivity of the method, they are in the order Tor $<$ Lev $<$ Mox $<$ Pse.

\section{Conclusion}

$\mathrm{KmnO}_{4}$, an oxidizing agent in alkaline medium is found to oxidise drugs like LEV, MOX, PSE and TOR which are soluble in basic medium. One of the oxidizing products namely manganate ion absorbs maximally at 
$610 \mathrm{~nm}$, whose absorbance is the function of concentration of the drug. Kinetics of the reaction is followed for quantification, construction of calibration, validation and optimization of the method.

\section{Acknowledgement}

The authors are thankfull to the Head, Department of Chemistry, Nizam college, Osmania University, Hyderabad-500001 for providing research facilities.

\section{References}

[1]. Neetu sachan $1^{*}$, phool chandra1, mayank yadav2., simple and validated uv-spectrophotometric method for the estimation oflevofloxacin in bulk and pharmaceutical dosage forms., Int J Pharm Pharm Sci, Vol 4, Suppl 5, 383-385

[2]. Liu, Fang-qun; Lu, Hong., Determination of levofloxacin in human plasma by HPLC.,ZhongnanYaoxue (2012), 10(10), $734-736$.

[3]. Cai, Jiayu; Sun, Shumao; Meng, Yongchun; Nan, Kaihui., Determination of levofloxacin hydrochloride in microspheres by HPLC.,ZhongguoXiandaiYingyongYaoxue (2012), 29(5), 437-440.

[4]. Manimala, M.; Ravindra, Reddy K.; Hepcykala, Rani D., Development and validation of novel UV spectrophotometric determination of levofloxacin hemihydrate in bulk and pharmaceutical dosage forms.,PharmaChemica (2013), 5(1), 47-50.

[5]. Hu, Wei-ping; Wang, Xin; Dong, Xue-zhi; Zhang, Lei; Jiao, Man., Determination of levofloxacin with congo red-malachite greenlevofloxacin system by spectrophotometry.,FenxiKexueXuebao (2012), 28(2), 257-260.

[6]. Peixoto Da Silva, Arnaldo; Luna, AdervalSeverino; Costa, Thais Malcher Da Silva; Aucelio, Ricardo Queiroz; Braga, JezWillian Batista; Boque, Ricard; Ferre, Joan., Spectrofluorimetric determination of levofloxacin in pharmaceuticals and in human urine.,International Journal of Life Science and Pharma Research (2012), 2(1), 147-158.

[7]. Maryadele.J.O. The Merck Index: An encyclopedia of chemicals, drugs and biologicals, 14th ed. New Jersey:Published by Merck Research Laboratories, Division of Merck and Co.,Inc. Whitehousestation:2001.p.1125.

[8]. British Pharmacopoeia, The Stationary Office Medicinal and Pharmaceutical Substances,London, 2009, 2, 1401

[9]. Wang, Nan; Zhu, Liqin; Zhao, Xuequn; Yang, Wenjie; Sun, He., Improved HPLC method for the determination of moxifloxacin in application to a pharmacokinetics study in patientswith infectious diseases.,ISRN Pharmacology (2013), 462918, 7 pp..

[10]. Abdelaziz, Ahmed A.; Elbanna, Tarek E.; Gamaleldeen, Noha M., Validated microbiological and HPLC methods for the determination of moxifloxacin in pharmaceutical preparations and human plasma.,Brazilian Journal of Microbiology (2012), 43(4), 1291-1301.

[11]. Xi, Hui-ping; Shi, Zhao-zhong., Determination of moxifloxacin residues in milk by fluorimetry method., ZhongguoYaofang (2012), 23(45), 4289-4291.

[12]. Cai, Hua-zhen; Xi, Hui-ping; Guo, Hai-xing., Fluorometric determination of moxifloxacin with calcein-congo red., FenxiShiyanshi (2011), 30(4), 86-88

[13]. Elbashir, Abdalla A.; Ebraheem, Sara A. M.; Elwagee, Alawia H. E.; Aboul-Enein, Hassan Y., New spectrophotometric methods for the determination of moxifloxacin in pharmaceutical formulations.,ActaChimicaSlovenica (2013), 60(1), 159-165.

[14]. El-Hawary, W. F.; Al-Gethami, Faisal Kh., Mutual spectrophotometric determination of Moxifloxacin drug and iron(III) ions by formation of a complex compound.,European Chemical Bulletin (2013), 2(1), 22-27.

[15]. Long, Ning; Zhu, Ming-fang; Yan, Zhi-hong; Zou, Yan., Anodic adsorptive voltammetric determination of moxifloxacin hydrochloride.,LihuaJianyan, Huaxue Fence (2012), 48(1), 37-39.

[16]. T. C. Westfall and D. P. Westfall, "Adrenergic agonists and antagonists." Goodman and Gilman's the pharmacological basis of therapeutics, editor, L. L. Brunton, J. S. Lazo and K. L. Parker, 11th ed, McGraw-Hill, New York, 2006, p. 260.

[17]. Sharma, M. C., UV-spectrophotometric, RP-HPLC and TLC densitometric determination of pseudoephedrine sulphate anddesloratadine in pharmaceutical dosage forms., Oxidation Communications (2013), 36(2), 422-431.

[18]. Kumudhavalli, M. V.; Saravanan, C.; Kumar, M.; Jayakar, B., Determination of pseudoephedrine hydrochloride, cetirizine dihydrochloride and paracetamol uncoated tablet by RPHPLCmethod.,Journal of Global Pharma Technology (2010), 2(4), 97-101

[19]. Li, Xianfeng; Zhu, Pingchuan., Simultaneous determination of pseudoephedrine hydrochloride and codeine phosphate in human plasma by capillaryelectrophoresis., Hubei DaxueXuebao, ZiranKexueban (2011), 33(4), 525-527.

[20]. Balamurugan, Krishnamoorthy; Gokulakrishnan, Kannan., Spectrophotometric method for the determination of pseudoephedrine in bulk and formulations.,Analytical Chemistry: An Indian Journal (2011), 10(6), 390-393

[21]. Riahi, Siavash; Hadiloo, Farshad; Milani, Seyed Mohammad R.; Davarkhah, Nazila; Ganjali, Mohammad R.; Norouzi, Parviz; Seyfi, Payam., new technique for spectrophotometric determination of pseudoephedrine and guaifenesin in syrup and syntheticmixture.,Drug Testing and Analysis (2011), 3(5), 319-324

[22]. Liu, Yu; Ren, Xiuhua., Determination of pseudoephedrine hydrochloride in human plasma by LC/MS/MS., YiyaoDaobao (2010), 29(12), 1563-1565.

[23]. Tan, Fei; Jiang, Xue-hua; Ren, Jing; Zhang, Yan; Lan, Ke; Wang, Ling; Tian, Yang., Determination of pseudoephedrine hydrochloride in human plasma by LC-MS/MS.,HuaxiYaoxueZazhi (2010), 25(1), 100-102.

[24]. J.L. Blose, K.F. Adams, J H. Patterson; Ann Pharmaco Ther., 1995, 29:396-402.

[25]. S.F. Flower, K.M. Murray; Am J Health Syst. Pharm., 1995, 52: 1771-1780.

[26]. Nilesh Jain*1, Ruchi Jain, Navneet Thakur, Brahm Prakash Gupta, Jitendra Banweer and Surendra Jain., Novel Spectrophotometric Quantitative Estimation of Torsemide inTablets Using Mixed Hydrotropic Agent., Der Pharmacia Lettre, 2010, 2(3):249-254

[27]. Krishna, MarothuVamsi; Sankar, DannanaGowri., Colorimetric determination of torsemide in pure form and in pharmaceutical formulations by using redox reactions.,ActaCiencialndica, Chemistry (2006), 32(4), 355-358.

[28]. Sankar, D. Gowri; Babu, P. Joy; Sujatha, N.; Latha, P. V. Madhavi., UV-spectrophotometric determination of torsemide and fenoverine.,Asian Journal of Chemistry (2006), 18(4), 3247-3248. 


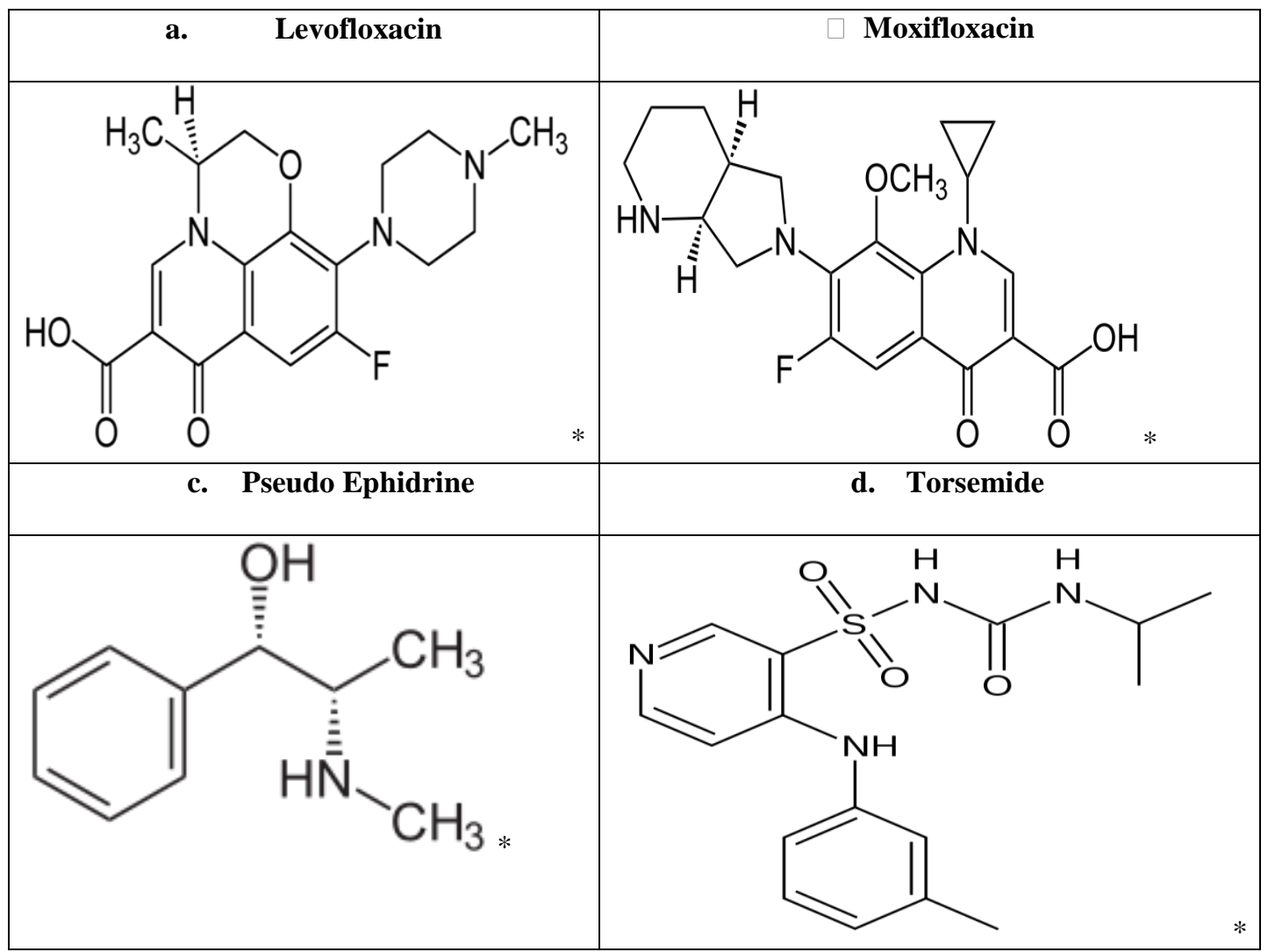

Figure 1: Structures of the Drugs

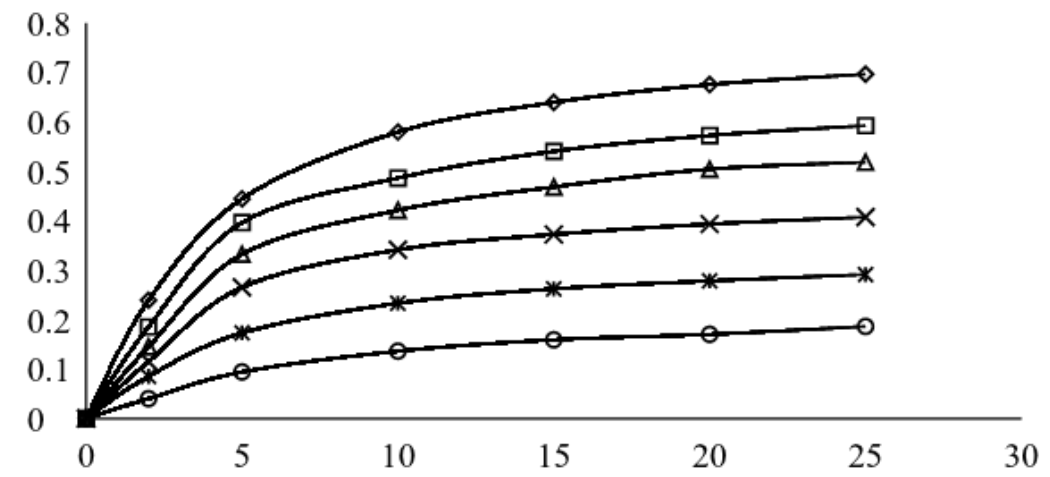

Figure 2: Absorbance -Time curves for the reaction of Drugs with Alkaline $\mathrm{KMnO}_{4}$

Figure 3: Calibration Curves

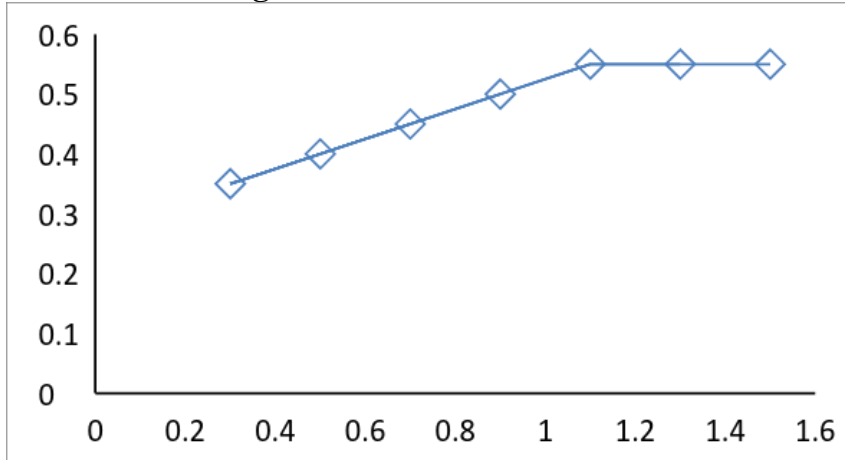

Fig 5: Effect of $\mathrm{KMnO}_{4}$ on Absorbance 
Fig 6 : Effect of $\mathrm{NaOH}$ on the Absorbance

\begin{tabular}{|l|l|l|l|l|}
\hline Name of Drug Property & LEV & MOX & PSE & TOR \\
\hline$\lambda$ max & 610 & 610 & 610 & 610 \\
\hline Beer's law limits $\left(\mu \mathrm{gmL}^{-1}\right)$ & $6.25-37.5$ & $5-30$ & $6.25-37.5$ & $2.5-15$ \\
\hline Sandell's sensitivity $\left(\mu \mathrm{gcm}^{-2}\right)$ & 0.044 & 0.048 & 0.048 & 0.0262 \\
\hline $\begin{array}{l}\text { Std. Dev. } \\
\text { of intercepts }\end{array}$ & 0.00234 & 0.0075 & 0.003977 & 0.0128 \\
\hline LOD $\left(\mu \mathrm{gmL}^{-1}\right)$ & 0.338 & 1.18 & 0.65 & 0.11 \\
\hline LOQ $\left(\mu \mathrm{gmL}^{-1}\right)$ & 1.025 & 3.57 & 1.99 & 0.34 \\
\hline Slope, b & 0.0228 & 0.021 & 0.0207 & 0.038 \\
\hline Intercept, a & 0.1486 & 0.1288 & 0.1086 & 0.074 \\
\hline Correlation coefficient & 0.9975 & 0.9971 & 0.9962 & 0.998 \\
\hline $\begin{array}{l}\text { Regression equation } \\
\text { Y=a+bx }\end{array}$ & $0.1486+$ & $0.1288+$ & $0.1086+$ & $0.0742+$ \\
& $0.0228 \mathrm{X}$ & $0.021 \mathrm{X}$ & $0.0207 \mathrm{X}$ & $0.0381 \mathrm{X}$ \\
\hline
\end{tabular}

$\mathrm{X}=$ Concentration of the Drug, $\left(\mu \mathrm{g} \mathrm{ml}^{-1}\right)$

Table 1 : Analytical Parameters for determination of drugs by oxidation with alkaline $\mathrm{KMnO}_{4}$

\begin{tabular}{|c|c|c|c|c|c|c|c|c|}
\hline $\begin{array}{l}\text { Name of the } \\
\text { Drug }\end{array}$ & $\begin{array}{l}\text { Amount Taken } \\
\left(\mu \mathrm{g} \mathrm{ml}^{-1}\right)\end{array}$ & $\begin{array}{l}\text { Amount Found } \\
\qquad\left(\mu \mathrm{g} \mathrm{ml}^{-1}\right)\end{array}$ & $\%$ Recovery & RSD \% & $\begin{array}{c}\text { Proposed method } \\
\text { Mean } \\
\pm \mathrm{SD}\end{array}$ & $\begin{array}{l}\text { Ref method } \\
\text { Mean } \\
\pm \mathrm{SD}\end{array}$ & $\begin{array}{l}\text { t-test } \\
(*)\end{array}$ & $\begin{array}{c}\text { F-test } \\
(* *)\end{array}$ \\
\hline LEV & $\begin{array}{l}8 \\
15 \\
22 \\
29\end{array}$ & $\begin{array}{l}8.07 \\
14.95 \\
22.09 \\
28.91\end{array}$ & $\begin{array}{l}100.87 \\
99.66 \\
100.41 \\
99.68\end{array}$ & 0.587 & $\begin{array}{l}100.16 \\
\pm 0.588\end{array}$ & $\begin{array}{l}{[136]} \\
99.62 \\
\pm 0.788\end{array}$ & $\begin{array}{l}0.478 \\
(2.45)\end{array}$ & $\begin{array}{l}0.557 \\
(4.28)\end{array}$ \\
\hline MOX & $\begin{array}{l}5 \\
10 \\
15 \\
20 \\
\end{array}$ & $\begin{array}{l}4.98 \\
10.1 \\
15.06 \\
19.75 \\
\end{array}$ & $\begin{array}{l}99.6 \\
101 \\
100.4 \\
98.75 \\
\end{array}$ & 0.978 & $\begin{array}{c}99.94 \\
\pm 0.977\end{array}$ & $\begin{array}{l}{[143]} \\
100.093 \\
\pm 0.86\end{array}$ & $\begin{array}{l}0.201 \\
(2.45)\end{array}$ & $\begin{array}{l}1.292 \\
(4.28)\end{array}$ \\
\hline PSE & $\begin{array}{l}7 \\
14 \\
21 \\
28\end{array}$ & $\begin{array}{l}6.97 \\
14.09 \\
21.08 \\
28.4 \\
\end{array}$ & $\begin{array}{l}99.57 \\
100.64 \\
100.381 \\
101.42 \\
\end{array}$ & 0.761 & $\begin{array}{c}100.506 \\
\pm 0.765\end{array}$ & $\begin{array}{l}{[150]} \\
102.6 \\
\pm 0.78\end{array}$ & $\begin{array}{l}0.032 \\
(2.45)\end{array}$ & $\begin{array}{l}0.963 \\
(4.28)\end{array}$ \\
\hline TOR & $\begin{array}{l}3 \\
6 \\
9 \\
12 \\
\end{array}$ & $\begin{array}{l}2.97 \\
6.06 \\
8.95 \\
12.07 \\
\end{array}$ & $\begin{array}{l}99 \\
101 \\
99.44 \\
100.58 \\
\end{array}$ & 0.940 & $\begin{array}{l}100.01 \\
\pm 0.939\end{array}$ & $\begin{array}{l}{[129]} \\
99.16 \\
\pm 0.59\end{array}$ & $\begin{array}{l}0.771 \\
(2.57)\end{array}$ & $\begin{array}{l}2.540 \\
(4.28)\end{array}$ \\
\hline
\end{tabular}

$* \mathrm{t}$ - test and $* *$ F-test values from literature

Table 2: Recovery Studies to evaluate Accuracy and Precision for the Determination of Drugs by

Redox Reaction with Alkaline $\mathrm{KMnO}_{4}$

\begin{tabular}{|c|c|c|c|c|c|c|c|c|}
\hline $\begin{array}{l}\text { Name of the } \\
\text { Drug } \\
\text { (Tablet) }\end{array}$ & $\begin{array}{c}\text { Amount Taken } \\
\left(\mu \mathrm{g} \mathrm{ml}^{-1}\right)\end{array}$ & $\begin{array}{l}\text { Amount } \\
\text { Found } \\
\quad\left(\mu \mathrm{g} \mathrm{ml}^{-1}\right)\end{array}$ & $\begin{array}{c}\% \\
\text { Recovery }\end{array}$ & $\begin{array}{c}\text { RSD } \\
\%\end{array}$ & $\begin{array}{c}\text { Proposed } \\
\text { method } \\
\text { Mean } \\
\pm \text { SD }\end{array}$ & $\begin{array}{l}\text { Ref } \\
\text { method } \\
\text { Mean } \\
\pm \text { SD } \\
\end{array}$ & $\begin{array}{l}\text { t-test } \\
(*)\end{array}$ & $\begin{array}{c}\text { F-test } \\
(* *)\end{array}$ \\
\hline $\begin{array}{l}\text { Lev } \\
\text { (Alevo) }\end{array}$ & $\begin{array}{l}9 \\
16 \\
23 \\
30\end{array}$ & $\begin{array}{l}9.07 \\
15.95 \\
23.09 \\
29.91\end{array}$ & $\begin{array}{l}100.78 \\
99.69 \\
100.39 \\
99.7\end{array}$ & 0.537 & $\begin{array}{l}100.14 \\
\pm 0.537\end{array}$ & $\begin{array}{l}136] \\
99.62 \\
\pm 0.788\end{array}$ & $\begin{array}{l}0.631 \\
(2.57)\end{array}$ & $\begin{array}{l}0.466 \\
(4.28)\end{array}$ \\
\hline $\begin{array}{l}\text { Mox } \\
\text { (Moxif) }\end{array}$ & $\begin{array}{l}6 \\
11 \\
16 \\
21 \\
\end{array}$ & $\begin{array}{l}5.98 \\
11.1 \\
16.06 \\
20.75 \\
\end{array}$ & $\begin{array}{l}99.67 \\
100.91 \\
100.37 \\
98.81 \\
\end{array}$ & 0.91 & $\begin{array}{c}99.94 \\
\pm 0.909\end{array}$ & $\begin{array}{l}{[143]} \\
100.093 \\
\pm 0.86\end{array}$ & $\begin{array}{l}0.089 \\
(2.45)\end{array}$ & $\begin{array}{l}1.118 \\
(4.28)\end{array}$ \\
\hline $\begin{array}{l}\text { Pse } \\
\text { (Alrid-D) }\end{array}$ & $\begin{array}{l}6 \\
13 \\
20 \\
27\end{array}$ & $\begin{array}{l}5.97 \\
13.09 \\
20.08 \\
27.4 \\
\end{array}$ & $\begin{array}{l}99.5 \\
100.69 \\
100.4 \\
101.48\end{array}$ & 0.81 & $\begin{array}{c}100.52 \\
\pm 0.82\end{array}$ & $\begin{array}{l}{[150]} \\
102.6 \\
\pm 0.78\end{array}$ & $\begin{array}{l}0.084 \\
(2.45)\end{array}$ & $\begin{array}{l}1.101 \\
(4.95)\end{array}$ \\
\hline $\begin{array}{l}\text { Tor } \\
\text { (Dytor) }\end{array}$ & $\begin{array}{l}4 \\
7 \\
10 \\
13\end{array}$ & $\begin{array}{l}3.97 \\
7.06 \\
9.95 \\
13.07\end{array}$ & $\begin{array}{l}99.25 \\
100.86 \\
99.5 \\
100.54\end{array}$ & 0.781 & $\begin{array}{l}100.03 \\
\pm 0.781\end{array}$ & $\begin{array}{l}{[129]} \\
99.16 \\
\pm 0.59\end{array}$ & $\begin{array}{l}0.492 \\
(2.45)\end{array}$ & $\begin{array}{l}1.754 \\
(4.95)\end{array}$ \\
\hline
\end{tabular}

Table 3: Application of proposed method for the analysis of studied drugs in pharmaceutical formulations by redox reaction with alkaline $\mathrm{KMnO}_{4}$ 